Alma Mater Studiorum - Università di Bologna DEPARTMENT OF ECONOMICS

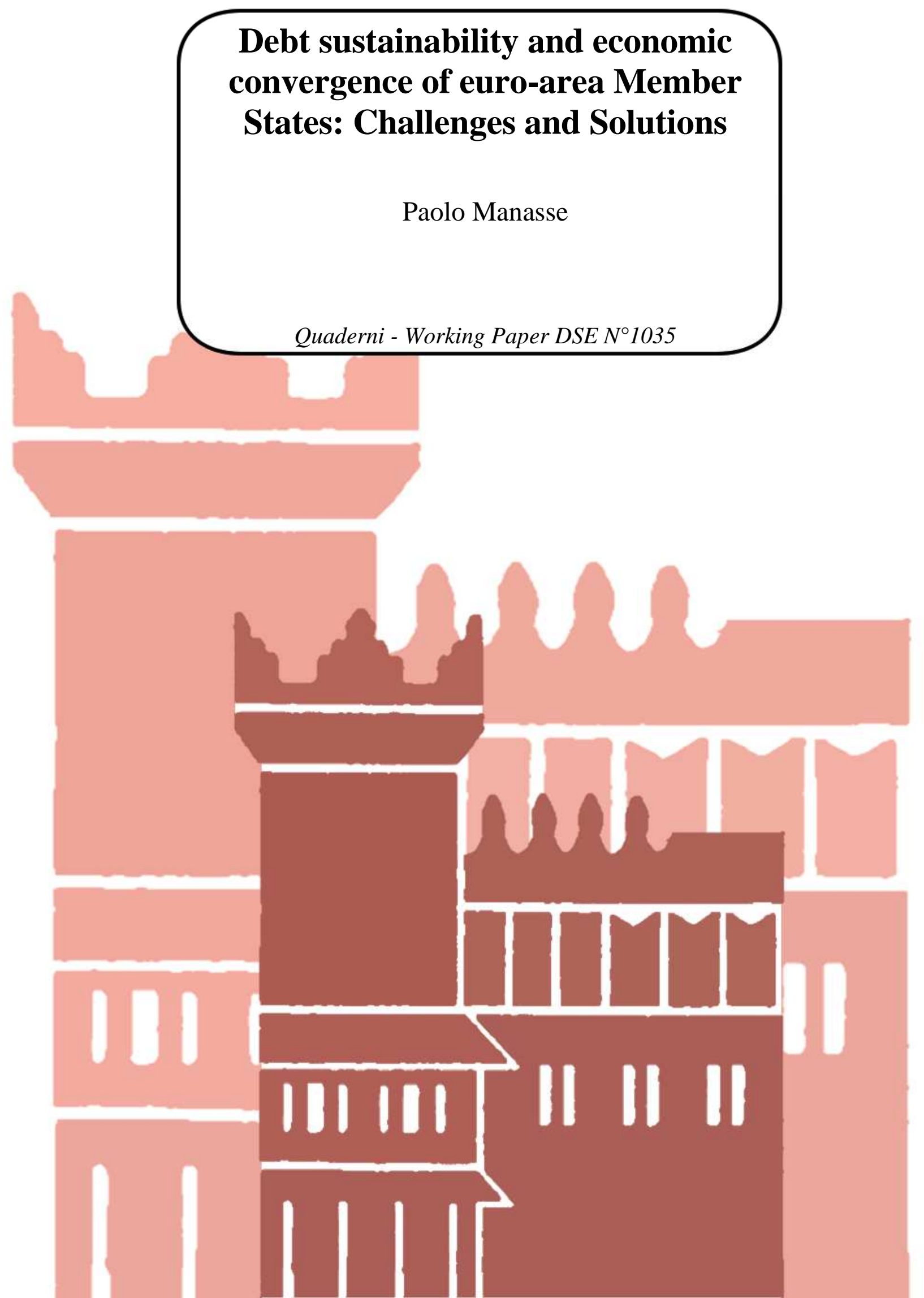




\title{
Debt sustainability and economic convergence of euro-area Member States: Challenges and Solutions
}

\author{
Paolo Manasse \\ Department of Economics, University of Bologna \\ paolo.manasse@unibo.it
}

October 2015

\begin{abstract}
This paper argues that fiscal convergence in the Euro area has been achieved at the expenses of real divergence in unemployment, investment and at, at least temporarily, growth. Statistical and econometric analysis support the view that the current fiscal framework has addressed debt sustainability concerns, but has imparted a pro-cyclical bias, which has contributed to economic divergence. The recent flexibility guidelines are a step in the right direction, but they are unlikely to have sizable effects. A reform of the fiscal framework and a mechanism for an intra-European unemployment insurance scheme is proposed.
\end{abstract}

Keywords: fiscal convergence, growth and stability pact, debt sustainability, procyclical fiscal policy

JEL Classification: E02, E61, E62, H6

This paper was requested by the European Parliament's Economic and Monetary Affairs Committee.

This paper was prepared for the European Parliament in advance of the Economic Dialogue with the President of the Eurogroup in ECON on 24 February 2014

This document is also available on Economic and Monetary Affairs Committee homepage, under section European Semester and Economic Dialogue at:

http://www.europarl.europa.eu/committees/en/ECON/home.html 


\section{CONTENTS}

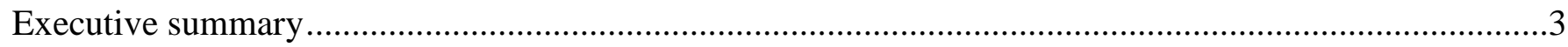

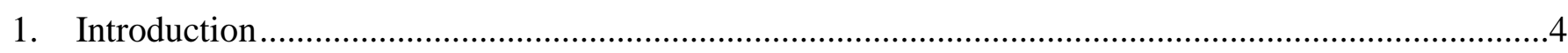

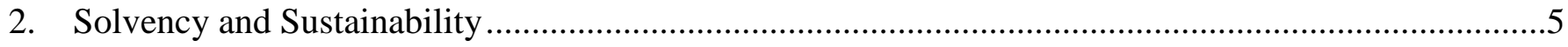

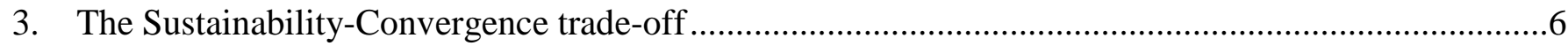

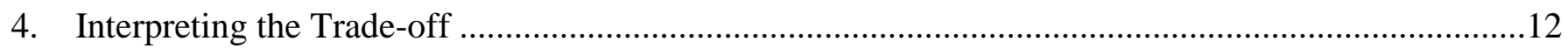

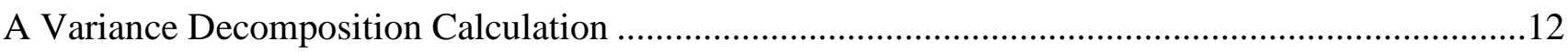

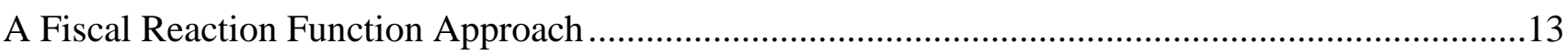

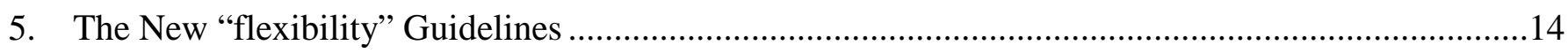

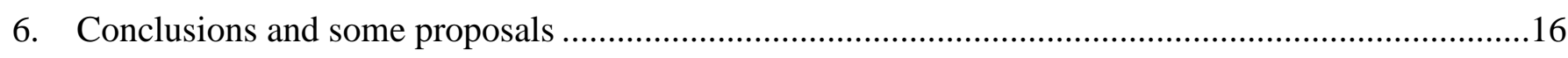

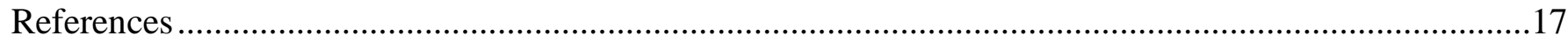

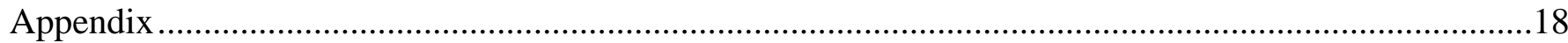

An application of the No Ponzi Game solvency condition.........................................................18

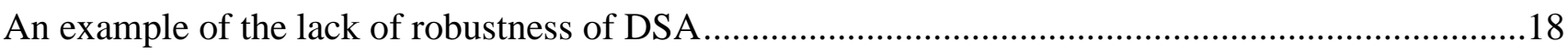

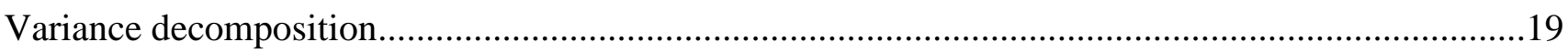

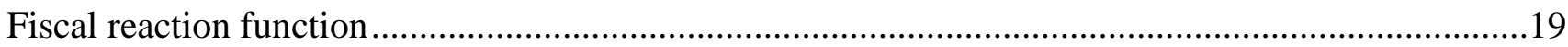

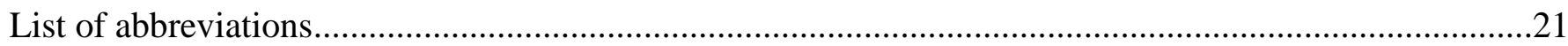

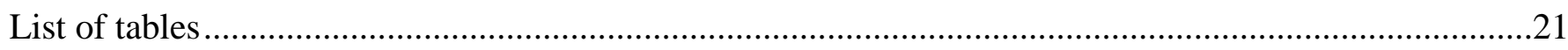

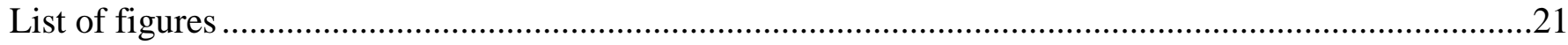




\section{EXECUTIVE SUMMARY}

This paper discusses the relationship between debt sustainability, the main goal of fiscal discipline, and economic convergence in the Euro area. Is there a trade-off between the two objectives? Does the current fiscal framework improve or compromise this trade-off? In the light of the recent changes in the Stability and Growth Pact, should the fiscal framework be amended in order to improve its effectiveness with respect to both objectives? What institutional reforms are needed in the European economic architecture?

The first section introduces the notions of solvency and sustainability. I argue that the theoretically correct definition of solvency is of little practical utility because it is very difficult to implement, while the more operational concept of debt sustainability suffers from not being robust to small changes in forecasts for growth, the interest rates and fiscal variables. I propose that these standard definitions should be supplemented by probabilistic measures that answer the question: what is the probability of a sovereign default?

Next I present evidence that during the crisis, budget positions in Euro Area member countries have converged, while their economies have diverged in several other dimensions: unemployment rates, investment, and, at least temporarily, growth. I argue that this process, if not reversed, can undermine the support for, and therefore the existence of, the common currency.

In order to understand the role of fiscal policy, I employ different approaches. First, I disentangle the role of country-specific shocks, possibly relating to product and labour market rigidities, from the role of policy-induced and common shocks, related to fiscal and monetary policies. While the former have contributed to raising the cross-country differences in debt ratios, I conclude that common shocks related to fiscal and monetary policies seem to have played an important offsetting role. This finding is consistent with the explanation that fiscal convergence in deficit/GDP ratios may have contributed to the divergence along the above mentioned economic dimensions.

Second, I describe the way in which fiscal policies have reacted to debt sustainability and to cyclical considerations during the crisis. To this end, I estimate a simple "fiscal reaction function". Consistently with the previous findings, I conclude that fiscal policy has strongly targeted debt sustainability, but was largely pro-cyclical during the crisis, possibly exacerbating business cycle swings.

The paper also discusses the recent guidelines for flexibility in the Stability and Growth Pact. I argue that the guidelines address exactly the correct issues, those described in the paper: procyclical policies, investment and incentives for reforms. The structural reform clause, that exchanges fiscal flexibility for reforms, is the most effective part. The investment clause is likely to be ineffective, because it only concerns a very limited number of projects. The cyclical clause is excessively complex and does not remove the pro-cyclical bias documented in the paper.

The final section contains some proposals of reforms of the Euro area economic governance. A country's negative output gap should not simply imply slower domestic fiscal adjustment: it should be dealt at the level of the Euro area. I discuss the proposal of setting up a Euro-budget for countercyclical policies, for example a European Unemployment Insurance scheme, were national unemployment schemes should be pooled. I also discuss a reform of the actual Stability and Growth Pact along three directions: simplification and focus on debt targets, more incentives for structural reforms, more individual freedom in allocating over time the agreed consolidation effort, a credible no-bail out clause. 


\section{INTRODUCTION}

Since 2008 countries in the Euro Area have experienced an unprecedented recession that has shaken the foundations of the common currency and jeopardized the European cohesion.

A sharp fall in output, originally stemming from the US subprime and banking crisis, led to a freeze in the European inter-bank lending, an impeding disintegration of capital markets, wide-spread insolvencies of European sovereigns and banks. Capitals flew away from European countries perceived to be at risk of default, such as those in the "periphery", and into countries considered to be "safe". Banks in the periphery were effectively cut-off from the international bank lending, as banks in other countries perceived them to be risky, given their exposure to domestic sovereigns. As a result, sovereign bond spreads exploded, the inter-bank market froze, and financial markets started to price into interest rates of the periphery a premium to compensate for the risk of their exit from the Euro. Moreover, the credit crunch on banks and the sharp rise in government borrowing cost aggravated the recession. In the Euro area as a whole, governments revenues fell, due to the contraction in output, and government expenditures rose (sometimes for bailing out banks, e.g. in Ireland, Spain and Belgium), worsening budget deficits and raising public debt.

The European Union's response was a program of international lending and bail-out/in, a frontloaded fiscal consolidation, the active intervention by the ECB supporting banks' liquidity needs and governments, and the creation of new institutions dealing with financial surveillance, emergency lending and banking union.

This multi-pronged approach has so far been successful in preventing the break-up of the Euro area. Moreover, fiscal discipline was restored and public debt was brought back under control. However, the side-effect was that the European economy plunged into a recession of unprecedented depth and persistence, and European economies started to diverge along many dimensions: unemployment, investment, and at least temporarily, growth. Should this trend persist, it may undermine the existence of the common currency and be a corrosive factor for the entire European project. This challenge is particularly serious for the Euro area, given that there exists no effective mechanism for inter-European redistribution and risk-sharing.

This paper discusses the relationship between debt sustainability, the main goal of fiscal discipline, and economic convergence in the Euro area. Is there a trade-off between the two objectives? Does the current fiscal framework improve or compromise this trade-off? In the light of the recent changes in the Stability and Growth Pact, should the fiscal framework be amended in order to improve its effectiveness with respect to both objectives? The plan of the paper is the following.

Section 2 discusses some preliminary methodological issues, and clarifies the often employed terms of "solvency" and "debt sustainability". I propose that these standard definitions should be supplemented by probabilistic measures.

In Section 3 I present evidence on the fact that during the crisis, the budget positions of Euro member countries have converged, while their economies have diverged under several dimensions: unemployment rates, investment, and, at least temporarily, growth.

In Section 4 I employ a variance decomposition approach in order to disentangle the role of country-specific shocks, possibly relating product and labour market rigidities, from the role of policy-induced and common shocks, related to fiscal and monetary policies. Furthermore, I describe 
the way in which fiscal policies have reacted to debt sustainability and to cyclical considerations during the crisis. To this end, I estimate a simple "fiscal reaction function".

Section 5 discusses the recent guidelines for flexibility in the Stability and Growth Pact. I argue that the guidelines address the correct issues, but they are unlikely to have noticeable effects.

The final section contains some proposal of reforms of the Euro area economic governance: a European Unemployment Insurance scheme, and a reform of the Stability and Growth Pact.

\section{SOLVENCY AND SUSTAINABILITY}

Unlike monetary policy, whose main policy target, price stability, is uncontroversial, fiscal sustainability is a more elusive target. The Maastricht treaty and the Stability and Growth Pact and its revisions focus of debt and deficit as a ratio of GDP. The idea is that when public debt grows "too much" it eventually becomes "unsustainable". Debt and deficits, unlike price stability, should be understood as "intermediate", rather than "final", targets: variables that are more directly under the control of policymakers and that are closely related to the ultimate target: solvency. But what do we mean by sustainability and solvency? Are these different concepts? How can we measure them? This section clarifies these concepts, and argues that "solvency" is the theoretically correct concept, but it is difficult to implement; the concept of "sustainability" is more operational, although the conclusions one can derive are very sensitive to the small changes in the assumed path of fiscal variables, interest and growth rates. I end this section with some proposal for useful measures of solvency.

Formally, a government is solvent if the present value of current and future expected primary surpluses (the excess of tax revenues over expenditures net of interests) is sufficient to repay the outstanding debt (see Romer, 2011). If it is not, some form of repudiation, be it in the form of inflation, restructuring, or outright default, is required. In a currency area such as the Eurozone, a member's disorderly default has potentially very large spillovers on other members: it can undermine price stability, generate contagion and bank-runs, lead to the zone break up or require politically unpalatable fiscal transfers between members. But how do we know if a government is solvent?

The problem with implementing this definition of solvency is that future revenues and expenditures are not known, so that, for a given level of debt, an abrupt change in expectations can lead to a selffulfilling default. Afraid of losing money, investors may refuse to roll-over the government debt and may ask for principal repayment; the government would then lose access to the capital market, and be unable to meet its obligations, validating the fears of default. Clearly, this scenario is more likely the larger the debt relative to the country resources (GDP) and the larger the interest rate the government has to pay (which implies a lower present value of future surpluses). The point, however, unless on an explosive trajectory, a given level of debt relative to GDP can be consistent with a solvent or insolvent issuer. To some extent, solvency lies in the eyes of the beholder (or in economists' jargon, there may exist "multiple self-fulfilling equilibria").

A necessary condition for solvency is that the debtor should not use the proceeds of new borrowing to pay the interests on existing debt, e.g. he should not run a "Ponzi scheme". This condition requires that the growth rate of debt to GDP ratio does not exceed the difference between the nominal interest rate and the growth rate of nominal GDP growth. Implementing this solvency requirement is quite difficult, however. In fact, the countries that face low real interest rates, 
because they are perceived to be less risky, are paradoxically more likely to violate the solvency condition (see an example in the Appendix)

This problems have led to the more operational concept of "sustainability". This concept is routinely employed for example by the IMF (the so called Debt Sustainability Analysis, DSA) and other international organizations. From the budget constraint identity it is possible to construct debt scenarios based on assumption on primary balances, interest rates and GDP growth. Recent applications take into account the currency and maturity composition of the debt, the type of owner (domestic vs foreign, private vs public), the exchange rate regime, cyclical and political conditions Also, it is possible to construct different simulations where the consequences of different shocks (to output, inflation, interest rates etc) are evaluated, taking into account the fact these shocks are correlated with each other and with fiscal variables (see Celasun, Debrun, Ostry, 2006).

While DSA scenarios are quite useful for assessing a country's vulnerability to different shocks, they are very sensitive to the underlying assumptions on growth and interest rates. In the appendix, I show an example where, under plausible assumptions on the long-run primary balance $(1.5 \%$ of GDP) and the real interest rate (2.5\%), the maximum level of debt a country could technically sustain can vary between $75 \%$ and $300 \%$ (!) of GDP, for relatively minor changes in forecast growth rate (from 0.5 to $2 \%$ ). ${ }^{1}$

The way to avoid the pitfall of these indicators is to explicitly acknowledge the probabilistic nature of solvency. Rather than asking "is public debt sustainable?", the correct question is "what is the probability of a default?" There are basically two ways to answer this question. The first looks at asset prices and balance sheets in order to extract the probability of default that is implicit in them. The second considers the past experiences of default and tries to identify the vulnerabilities in fundamentals that are more likely to result in insolvencies or bail-outs.

An example of the former is the analysis of Credit Default Swaps for sovereign bonds. These are insurance contracts, traded daily, where the protection seller, typically a bank, commits to buy a bond from the protection seeker, at the nominal value, in case of a default. The price of insurance, expressed in terms of the value of the bond, can be used to recover the probability that two parties place on the default event (see Hull and White, 2000, and Manasse and Trigilia, 2010 for an application to Ireland and Italy). These default probabilities give the "pulse" of market perceptions. However, these are very volatile and are not suitable to assess a country's "fundamentals" resilience to solvency crises. Alternatively, sovereign default probabilities can be recovered by applying contingent claim analysis to the balance sheet of the government (see Gray, Merton and Bodie, 2007): what is crucial here is the quality of the data. Finally, "computer intensive" algorithms can be applied to past episodes of sovereign default in order to recover the combinations of characteristics that, with high probability, are conducive to sovereign default (for example, high level of external debt as a ratio of GDP, run-away inflation, short maturity of debt, fixed exchange rates, the proximity of elections, a sharp recession, see Manasse and Roubini, 2006). These probabilistic measures should complement the standard solvency/sustainability considerations.

\section{THE SUSTAINABILITY-CONVERGENCE TRADE-OFF}

One of the most striking aspects of the ongoing economic crisis in the Euro Area is that fiscal convergence among member countries has been associated to economic divergence along many dimensions. By fiscal convergence I mean that over time budgetary positions have become more

\footnotetext{
${ }^{1}$ The example disccussed in the Appendix makes the standard, although rather implaudsible assumption that the long term real interest rate, the rate of growth and the primary balance are independent from each other
} 
similar between Euro area members. By real divergence I mean a tendency of European economies to become more different in terms of unemployment rates, investment, and, at least temporarily, growth rates.

We know since the work of Robert Mundell (1961) that "asymmetries" between countries that share a common currency is problematic, in particular when international labor mobility is low, so that large differences in unemployment persist; when wage and price flexibility is limited, so that real shocks fall on employment and output levels rather than prices and wages; and when the area is not equipped with an insurance mechanisms that help countries in recession. Real divergence if not tackled, can undermine the political support for the common currency. This is already happening in Italy, France and, concerning EU membership, in the UK.

Let's start from fiscal convergence. Figure 1 shows the average, mean, maximum and minimum government structural balances expressed as a ratio of potential output. On average, fiscal stabilizers were allowed to operate between 2007 and 2009 when the average balance deteriorated from -2.8 to -5.4 percent of potential output (blue line). In this period the dispersion among Euro area members widened sharply. However, since 2009 a huge consolidation effort brought back the average structural balance to $-1.3 \%$ in 2014. Interestingly, the difference between the best (green line, Finland, Luxembourg) and worse (yellow line, Greece) fiscal performers shrank. The cross country dispersion of budget positions, the standard deviation of the structural balance/potential output ratio of the different countries at a point in time, the red line, took a plunge. A period of divergence in budgetary positions in the years before 2009 was followed by convergence there since: countries with larger deficits consolidated more.

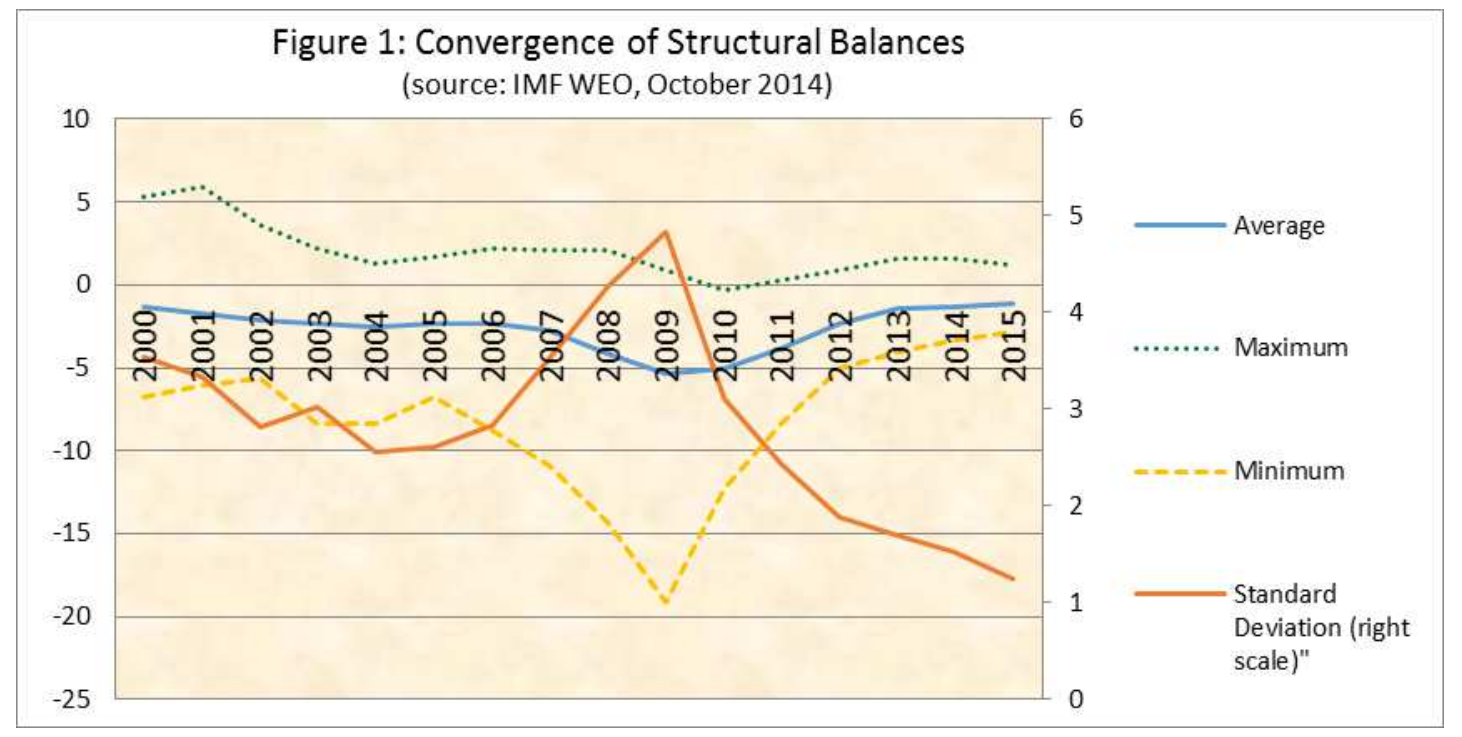

Figure 2a plots the average (un-weighted) debt/GDP ratio of Euro Area members, shown by the light-blue line (left scale). Since the start of the crisis in 2008, average debt rose from 52\% to $85 \%$ of GDP in 2014. In most countries this was the result of the e fall in output and the working of automatic stabilizers. In a few countries, such as Ireland, and to a lesser extent, Spain, this was due to the budgetary impact of bank rescue costs. The wedge between the largest and the smallest debt ratios (Greece, green dotted line and Estonia/Luxembourg, yellow dotted line, respectively) widened. The red line in Figure 2 shows the standard deviation normalized by the mean (the Coefficient of Variation, CV, right scale). This measures of dispersion increases in the period leading to the crisis, from 2004 to 2007, but since then it drops considerably, by one third, from the 
peak in $2007^{2}$. Unfortunately, the interpretation of this indicator is not unambiguous in this case, since its recent fall in reflects at least in part the rise in the mean value of Euro area debt.

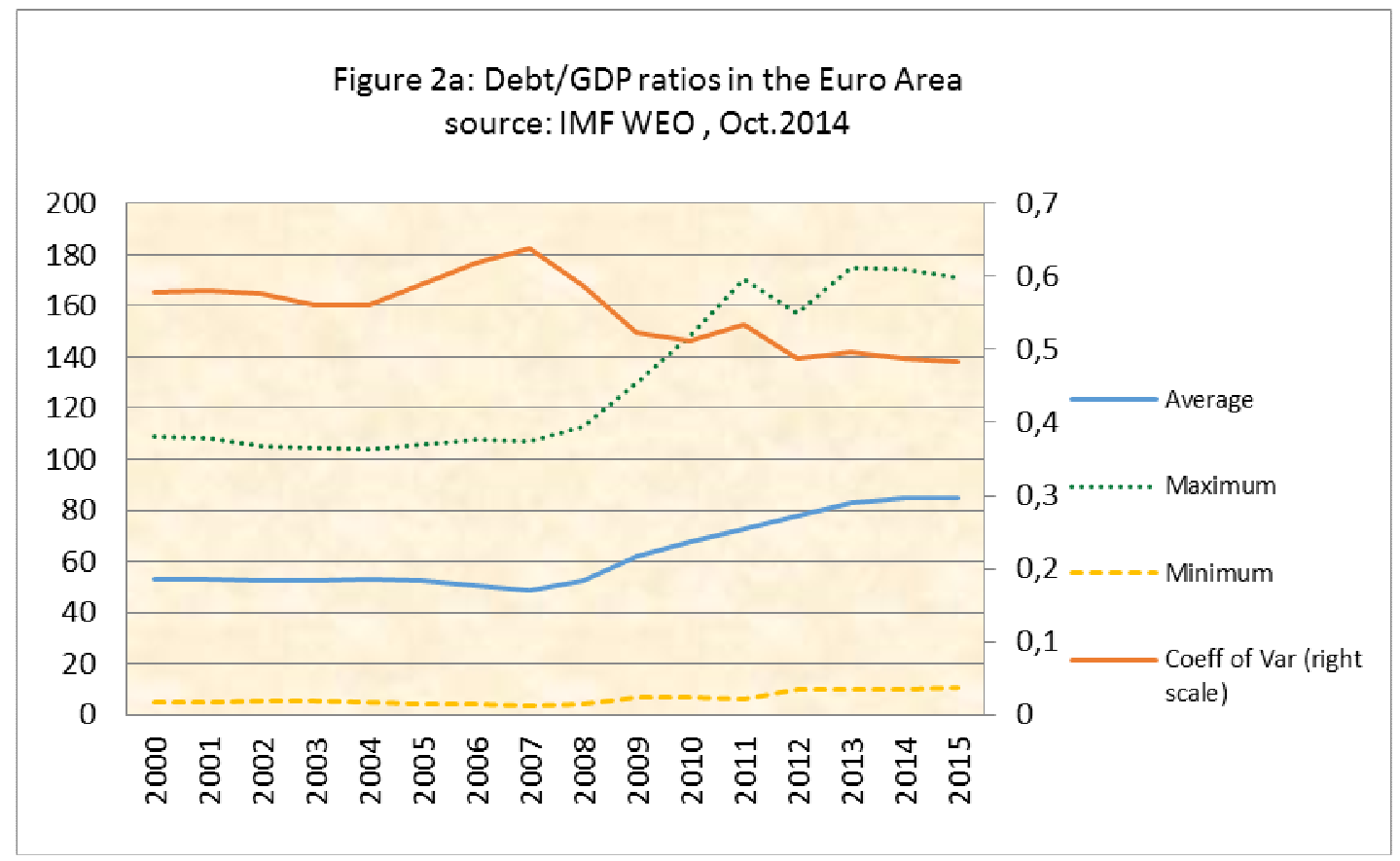

To shed more light on this issue, I concentrate on the evolution of the debt/GDP ratio since 2008 in Figure $2 b$. Each country is represented by a point. The $x$-axis reports the initial value of the debt ratio in 2008, while the y-axis shows the change in the ratio between 2008-2014. For convergence, we would require that high initial debts should be associated with low debt increases in the following period, a negative relationship. However, no clear such pattern emerges here

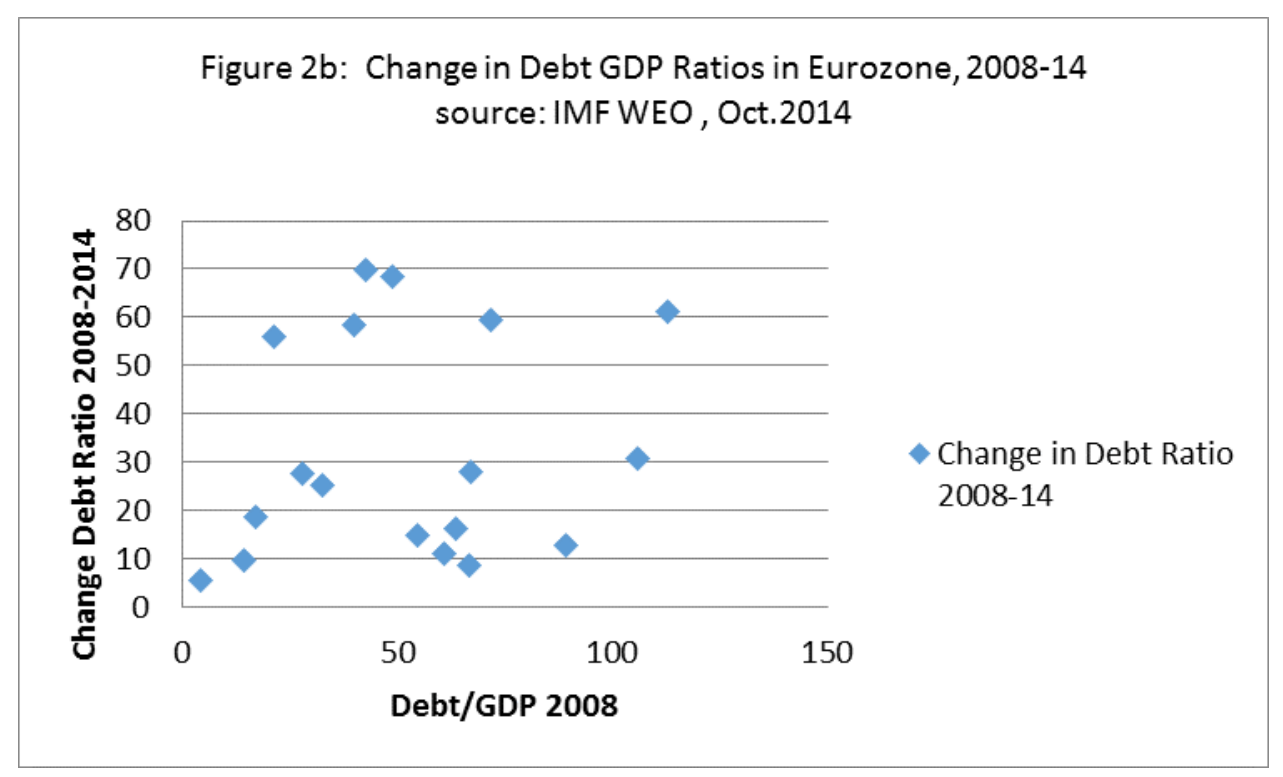

On the contrary, the European economies show clear elements of economic divergence. I will limit my discussion to unemployment, investment and growth.

\footnotetext{
${ }^{2}$ For debt /GDP ratio, investment and unemployment, I use the CV as a measure od dispersion because, normalizing for the average, this a pure number independent of the scale of measurement. However, for structural balances and growth rates, which occasionally take average values close to zero, I employ the standard deviation.
} 
Figure 3 depicts the dynamics of the rate of unemployment in the Euro area. On average, the rate of unemployment (blue) almost doubled since the crisis, rising from 6.2\% in 2007 to 11.8 in 2013 and moving slightly down since. The difference between the highest rate (Slovak Republic and then Greece, in green) and the lowest rate (Luxembourg in yellow), rose dramatically during the crisis, and correspondingly the coefficient of variation (in red, right scale) rose dramatically, reversing a period of convergence from 2000 to 2007.

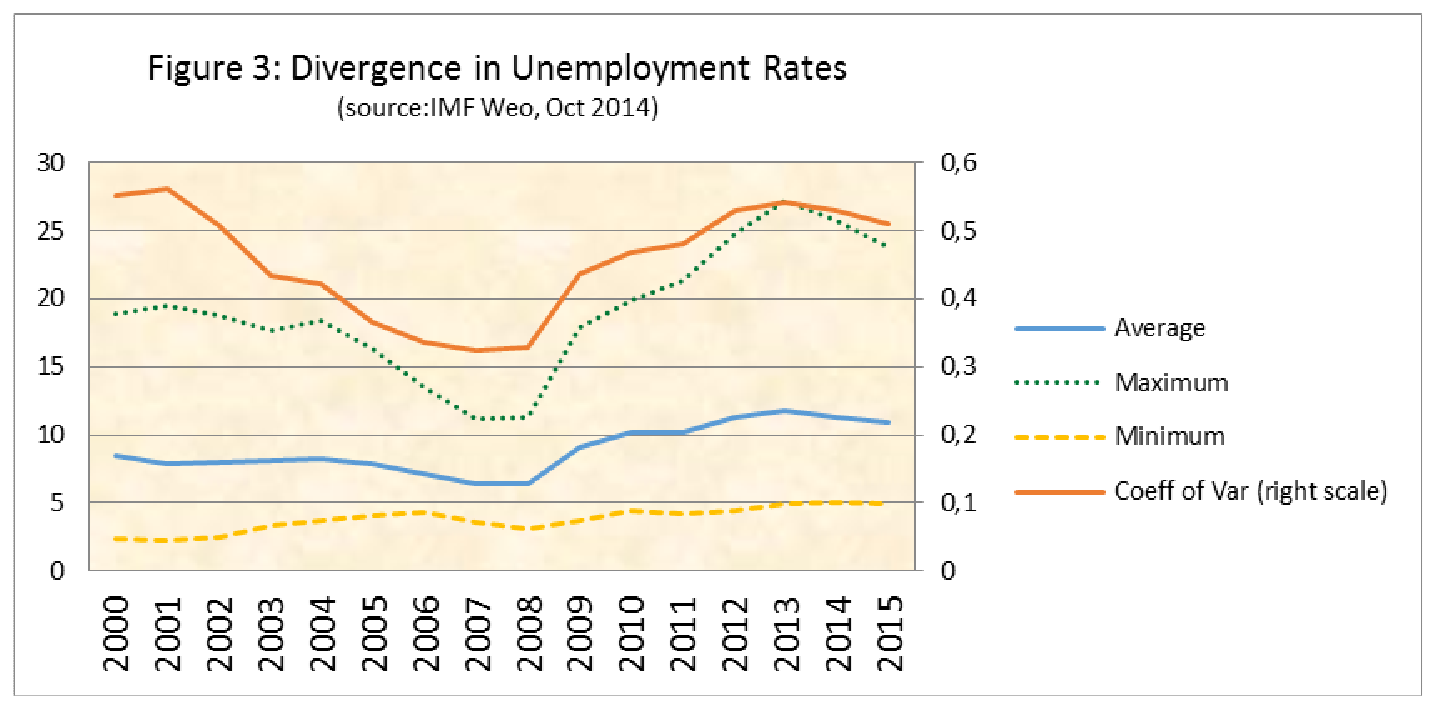

In Figure 4, I show the ratio of total (private and public) investment in GDP. The average ratio, blue line, shows a huge drop in 2007, when it fell from $27 \%$ to $20 \%$ of GDP in 2009 . Investment collapsed in all countries, but fell proportionately more were the share was larger. In fact the distance between the highest (Latvia) and the lowest (Germany) investment shares initially collapsed, due to the crash in the high share countries. Accordingly, our measure of cross-country dispersion (red line) more than halved between 2007 and 2010. From 2010 onward, however, the investment shares started to diverge again, almost reaching the peaks of the pre-crisis period. This time however, the divergence was mainly do to the drop in low-share countries (Cyprus).

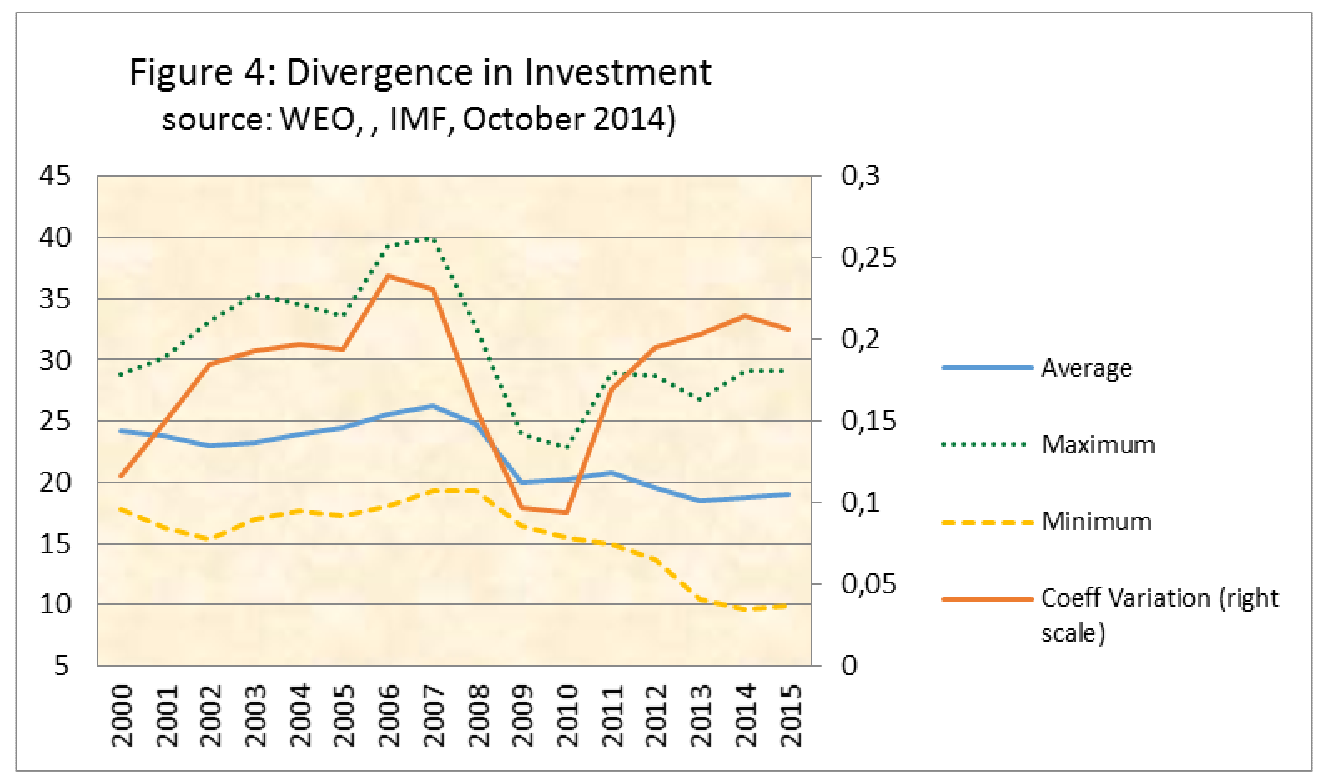

The dynamics of GDP growth is more ambigous, see Figure 5a. There is a double dip in average growth, first in 2008 and then in 2011 (blueline). Since then countries in the Euro area seem to have settle to a low growth equilibrium. The first recession goes together with a large rise in divergence, 
with the standard deviation spiking from 2.6 to 4.2 (right scale). The second recession in 2012 is preceeded by another rise in dispersion. Unlike the case of unemployment and investment, the rise in the dispersion of growth rates seems more temporary in nature, as both high and low growth countries are now converging to similar growth paths.

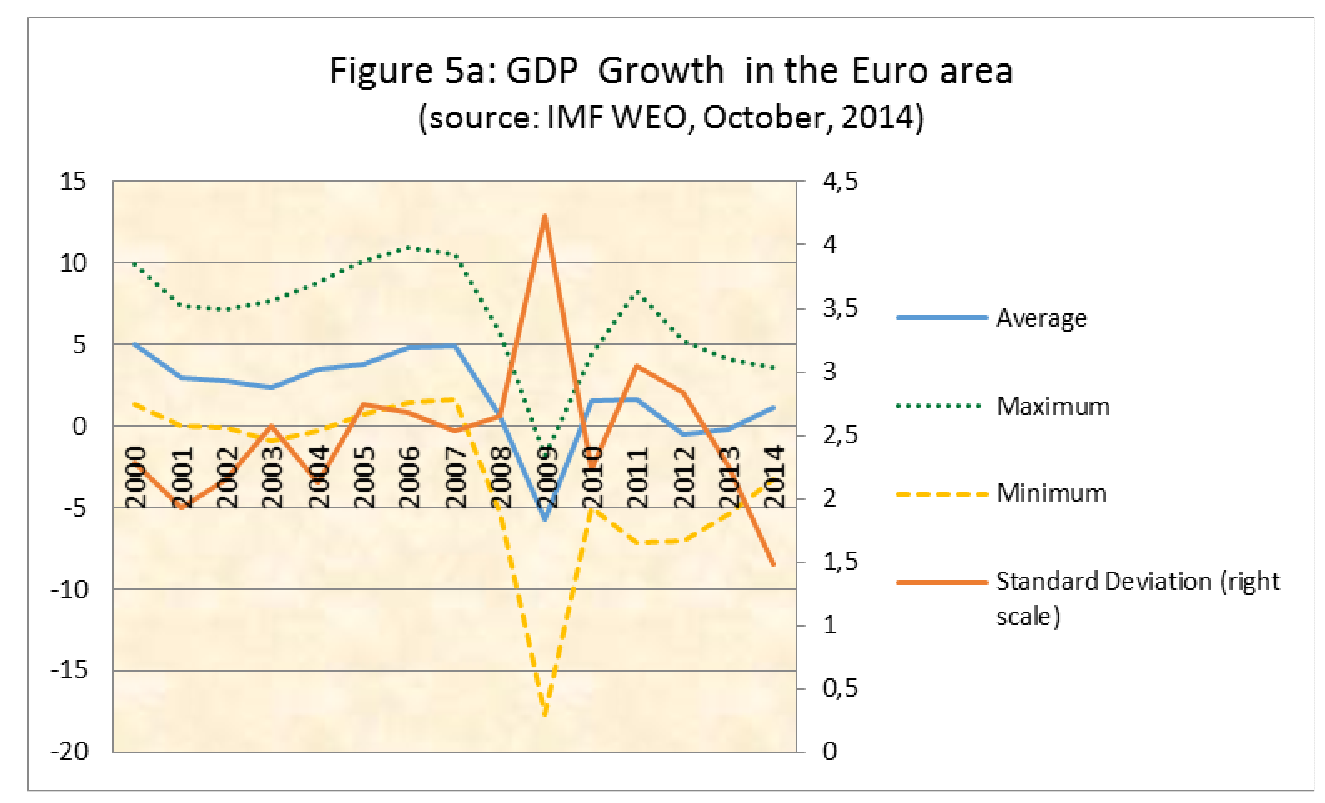

In order to dig on the issue of goriwth convergence/divergence, during the crisis years 2008-2014, Figure $5 \mathrm{~b}$ takes a different perspective. On the horizontal axis I plot the growth rate of GDP in 2008, and on the vertical axis I show the cumulated growth in the period 2008-2014. Each point represents a country. The fact the points lie on a positive sloped line implies that countries where growth was initially higher (lower), grew faster (slower) during the crisis. This picture implies divergence of growth rates since the crisis.

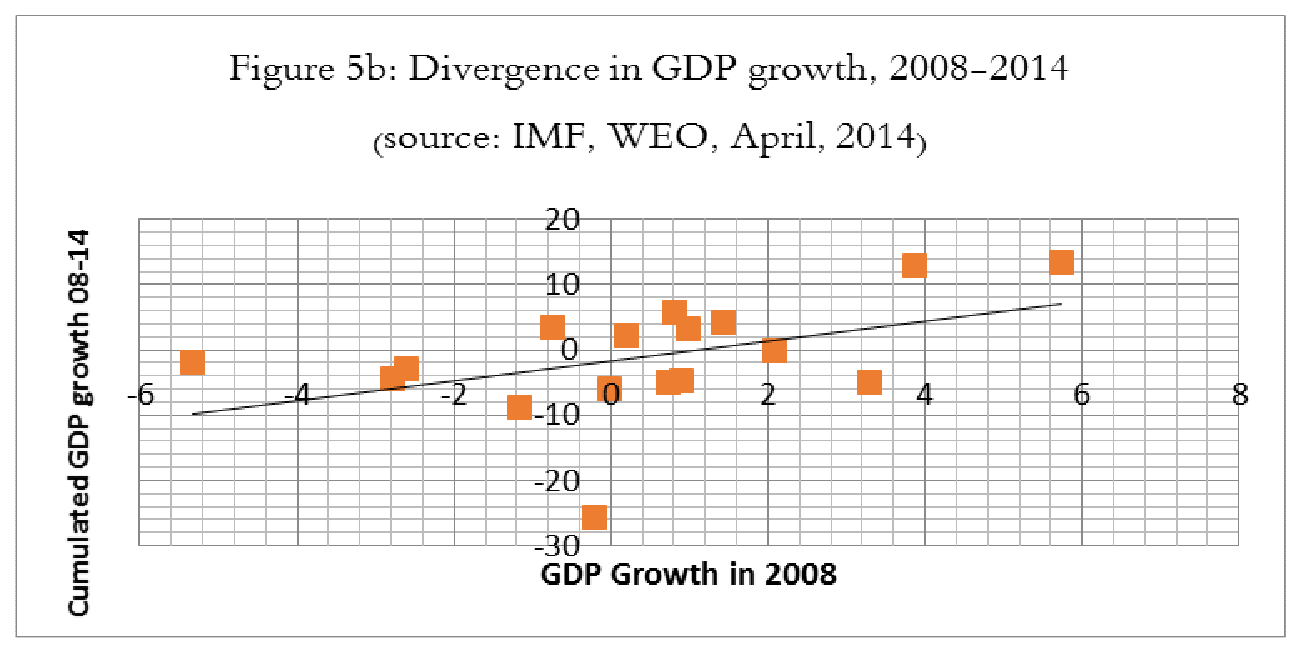

Many factors may have contributed to the examples of economic divergence illustrated before. They include supply and demand characteristics as well as features of the capital market.

Consider the consequences of an aggregate demand shock, for example a credit crunch stemming from a freeze of the interbank market, or a budget cut. The effects of a given demand shock depend on supply side features such as the degree of price and wage rigidity. If product markets are not competitive, firms can exploit their market power and keep price unaltered, so that the consequent 
fall in consumption will be larger; similarly, if wages do not adjust in the face of lower demand, firms will need larger cuts in employment. In Manasse and Rota Baldini, 2013, we present evidence that shows that

- $\quad$ the countries which experienced the larger rise in unemployment between 2008-12

are those where unemployment was higher in 2000-2008, implying that initial labour market distortions partly explain the subsequent rise in unemployment;

- the countries where per capita GDP declined more or grew less during the in the crisis are those where total factor productivity had risen less before the crisis, implying that those characteristics which inhibited productivity growth before the crisis largely account for the bad performances during the crisis.

Moreover, the degree of competition in the banking industry and the perceived riskiness of banks in high debt countries, together with the widening of interest spreads during the crisis, might have contributed to the severity of the credit crunch in peripheral countries, fostering the disparities in investment behaviour documented above.

Given the scope of this paper, I will focus on the role of fiscal policy. While budget cuts lead to lower demand at least in the short term, the size of the "fiscal multiplier" is controversial (see Blanchard, Leigh, 2013). Figure 6 shows the relationship between the dispersion debt/GDP ratios and the dispersion in unemployment rates (a similar relationship holds replacing the unemployment rate with GDP growth rate). On the vertical axis I plot the coefficient of variation (CV) of unemployment rates across Euro area countries in a given year, on the horizontal axis I show the $\mathrm{CV}$ of the debt-to-GDP ratio in the same year. Years of convergence in debt ratios (points towards the origin on the $\mathrm{x}$-axis) are on average associated to periods of divergence of unemployment rates (up on the y-axis), and vice versa. The figure shows that since 2000 there has been a trade-off between debt convergence and "real" convergence in the Euro area.

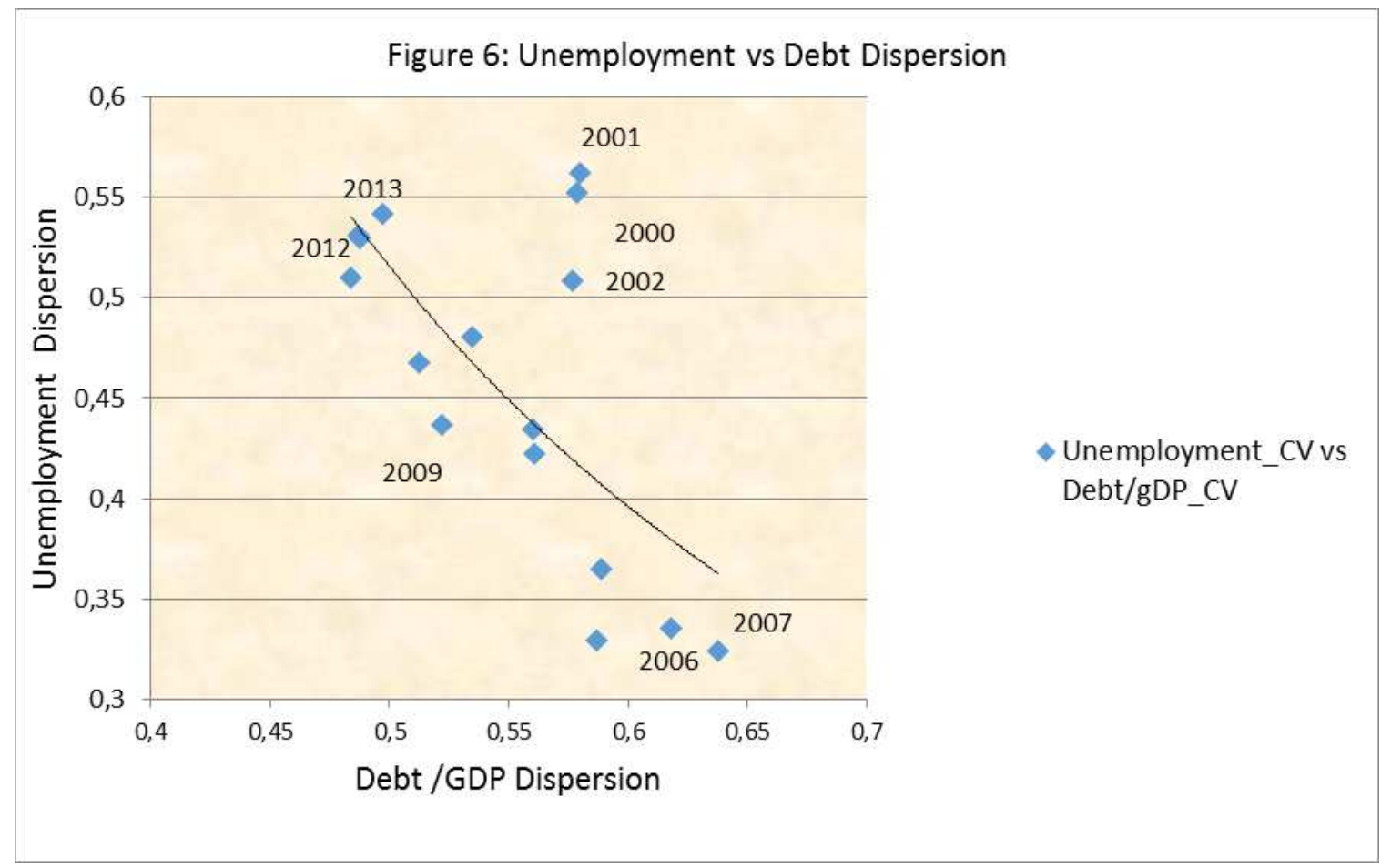




\section{INTERPRETING THE TRADE-OFF}

In order to understand to which extent fiscal convergence can explain real economic divergence in several dimensions in the Euro area, particularly during the crisis' years, I proceed in two steps. First, I decompose the differences in debt ratios into country-specific shocks and common/policy shock. The former capture for example supply side and credit markets characteristic, while the latter measure the importance of fiscal and monetary policies. Second, I estimate a "fiscal reaction function" in order to understand whether fiscal policy was pro or anti-cyclical in the Euro area, and the extent to which it targeted debt sustainability.

\section{A Variance Decomposition Calculation}

The measure of dispersion (variance) between the countries' debt ratios at each point in time can be approximated by the sum of three components (see Appendix 1). The first is the percentage contribution of the dispersion of nominal debts. This is represented by the red line in Figure 7. It rises when nominal debts become more different from the mean; the second is the percentage contribution of the dispersion between nominal GDPs (see the violet line in the figure): when this component rises, nominal incomes diverge in the euro area. These two terms account for countryspecific characteristics, and account for "asymmetric" responses possibly due to supply side and credit markets conditions. A bail-out of the banking sector, for example, would show up as a country-specific shock to nominal debt that would raise the debt dispersion among Euro area countries. The third term represents the percentage contribution of the co-movements between the two (yellow line). This "covariance" term is particularly interesting: when this term is positive, domestic debts tend to move together with domestic incomes. Thus this term captures either policyinduced changes or common shocks. One example of a policy induced change is a pro-cyclical fiscal policy. For example, if fiscal policy tightens and debt falls relatively more in countries where income falls, this would generate a positive covariance. The direction of causality could also be the opposite: for example, if a more restrictive budgetary policy leads to a stronger recession, this could also be reflected in a positive covariance term. Alternatively, a positive covariance could result from a common shock, for example a fall in inflation due to a restrictive monetary policy, which would reduce nominal debts along with nominal incomes in the different countries. Clearly, a positive co-movement between debt and income reduces the cross-country dispersion in debt ratios. The percentage contribution of this term to the dispersion in debt/GDP ratio is measured by the yellow line (with a minus sign)

Country-specific shocks in nominal GDP and debt contributed to raise the cross-country differences in debt ratios, from 2007 to 2013 (see Figure 7). Their individual shares of the total variance rose from 10 to 20 percent. What happened in this period, however, is that these two effects were almost exactly compensated by the "covariance" term, representing common and policy shocks, which also doubled, accounting for about $40 \%$ of total variance and contributing to reduce the disparities in debt/GDP ratios.

This exercise suggests that both asymmetric (such as bail-out) / supply factors and symmetric /demand factors were at work, with similar importance, during the crisis, pushing disparities in European debt ratios in opposite directions, which explains why the dispersion in debt ratios does not move unambiguously. 
Figure 7: Decomposing Debt/GDP Dispersion

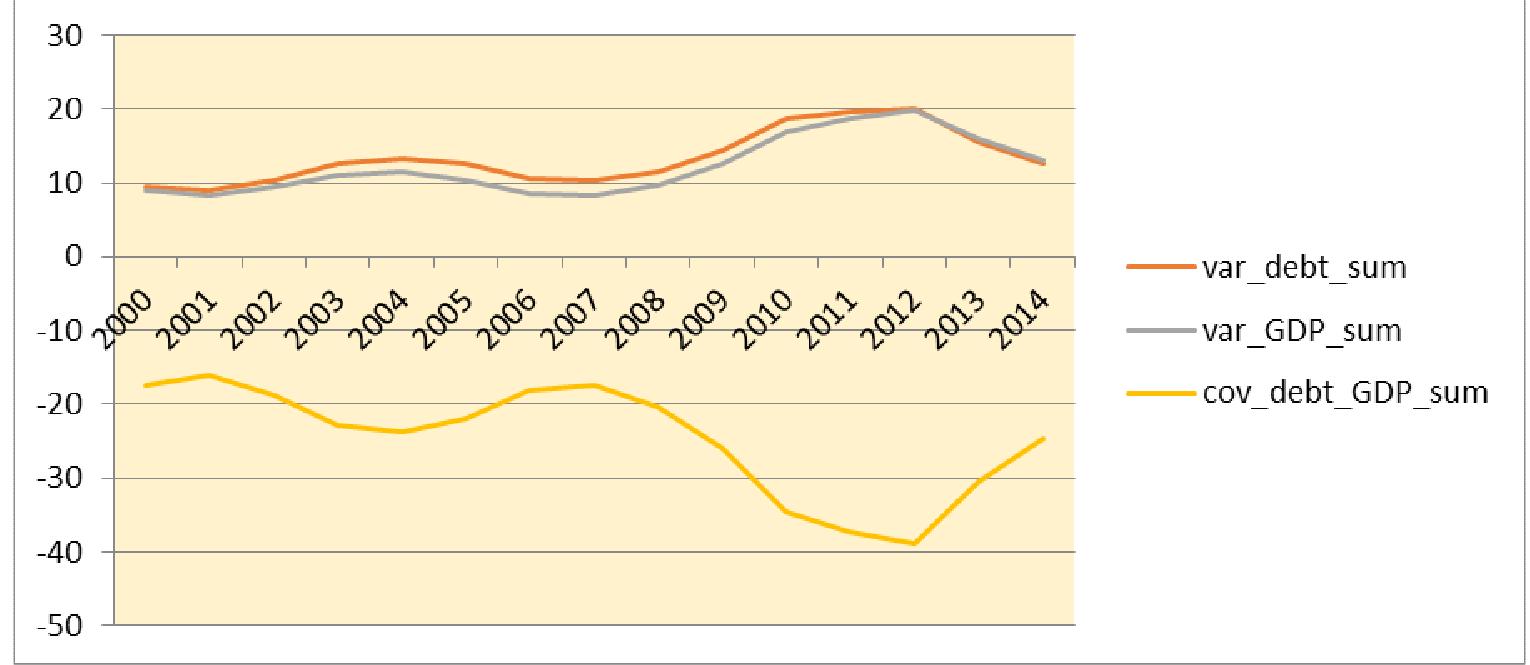

\section{A Fiscal Reaction Function Approach}

This section digs more into the role of fiscal policy, and in particular examines whether the fiscal consolidation effort that was undertaken in the Euro area since 2009 may account, at least partially, for the divergence of unemployment rates, investment and possibly growth, and the convergence of debt ratios and structural balances.

One way to describe the fiscal policy rule at the level of the Eurozone is to estimate a 'fiscal reaction function' (see Gavin, M and R Perotti, 1997, and Manasse, 2014). The idea is that a policy maker follows a particular discretionary policy by adjusting the primary balance to the ratio of debt to GDP and to the cyclical state of the economy in the previous period (see Appendix for the details). Debt sustainability considerations would require a larger increase in the surplus the larger the debt/GDP ratio. A cyclical stabilisation concern would require a lower increase in the surplus the lower is the economy's growth rate. The main results, obtained for the 18 Euro area countries in the period 2008-14 suggest that, on average, fiscal policy was tighter in more indebted countries, as expected, but also in countries where growth was lower, not higher. In particular I find that

- $\quad$ a one percent fall in the growth rate is on average associated with a cyclically adjusted primary balance tightening of almost one fourth of a percentage point of GDP. This estimate indicates that since 2008 the Eurozone fiscal framework has delivered a procyclical outcome, possibly exacerbating movements output.

- $\quad$ A ten percentage point increase in the debt to GDP ratio is associated to about a one percent rise in the primary surplus relative to potential output. This implies that fiscal policy has indeed targeted debt sustainability, being more restrictive where debt was higher. 


\section{THE NEW “FLEXIBILITY” GUIDELINES}

The evidence suggests that during the crisis the Euro area fiscal framework has focused mainly on fiscal sustainability, at the cost of implementing pro-cyclical policies. This interpretation is consistent with the observation budgetary positions have converged among Euro area countries, while divergences in unemployment rates, investment, and, partially growth, worsened.

In January the European Commission has issued guidelines on the Stability and Growth Pact (SGP) that aim precisely at contrasting pro-cyclical policies, favour investment and promote growth. The guidelines allow members to dilute the fiscal consolidation when cyclical conditions are particularly negative, when a country implements growth-friendly structural reforms, and provide more "fiscal space" for investment, particularly during recessions (see for a detailed discussion Manasse, 2015). The question addressed in this section is whether these changes will be enough to alleviate the procyclical bias of the current framework. The answer is that they are a step in the right direction, although their impact will be limited.

Consider the "structural reform" clause. This is the most convincing part. Structural reforms are costly to implement and there is evidence that in the short run may have a negative impact on the economy (see Aksoy, 2014). The "discount" in terms of lower fiscal consolidation can be substantial, up to half a point of GDP. A number of provisions make sure that the medium term objective (MTO) will not be waved, and that the 3 percent deficit /GDP limit will not be violated. Although the large discount applies only to Member States that are not subject to an Excessive Deficit Procedure (EDP), interestingly also these countries may be allowed "more time" for adjusting, even if the opportunity is conditional to having respected previous commitments under the EDP.

The "investment" clause says that the contributions to the new-born European Fund for Strategic Investment (EFSI) will not count in the debt and deficit criteria, and that some extra space for investment can be granted, in terms of deviations from the MTO, for countries in recession (negative growth, or output below potential by at least $1.5 \%$ ), for projects co-financed by the EU, and for countries not in EDP. Notice that the deductible contributions to the EFSI are quite limited, about 21 billions. Moreover, many countries with open EDP (Croatia, Cyprus, Portugal, Slovenia, Poland, France, Ireland, Greece, Spain) are also undergoing large recessions and will be eligible only for the exemptions of the capital contributions to the Fund, but not for the other co-financed investments . Moreover, the clause does not apply to non EU project: for example private-publicpartnerships (PPPs) are not eligible: the overall impact is likely to be minor.

Finally, the "cyclical clause" is quite problematic. In theory, it should eliminate the pro-cyclical bias that was documented above. In practice, it does not. The first problem is complexity: rather than simply identifying a recession with some standard definition, say at least two consecutive quarters of negative GDP growth, here a distinction is arbitrarily made between "exceptionally bad", ""very bad", "bad", "normal" and "good" times, and there are no less than three indicators defining where one stands (real GDP growth, the output gap, the rate of growth of potential output). Moreover, the cyclical correction is higher or lower depending on whether the debt/GDP ratio is above or below $60 \%$. In Figure 8 I plot the size of the required adjustment (vertical axis) as 
a function of the output gap (horizontal axis) and of the difference between actual and potential growth (the width axis), for the case of debt/GDP ratio exceeding $60 \%$ (the rules are softer when debt is below $60 \%$ of GDP).

Figure 8. The cyclical conditions and the fiscal adjustment

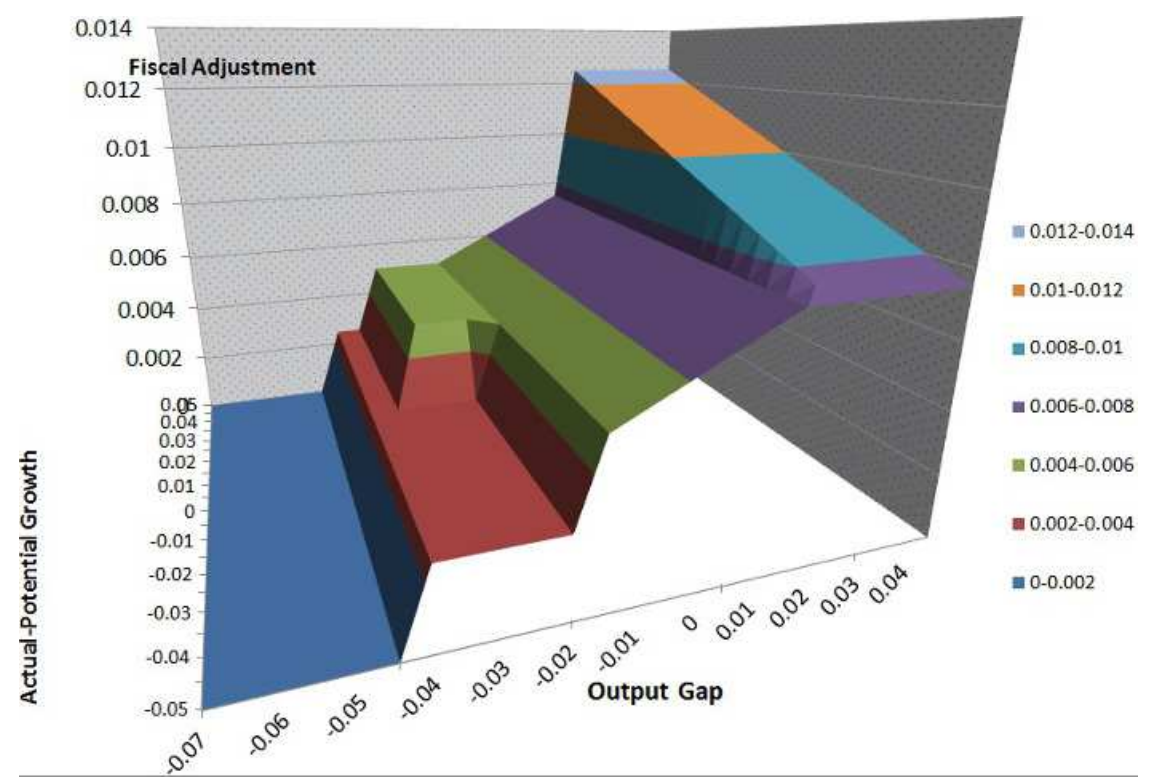

In "exceptionally bad" times, (output gap below $-4 \%$ or negative GDP growth), the adjustment is zero. Yet fiscal consolidation rises to no less than 0.25 (for countries with debt-to-GDP ratio above $60 \%$ or with sustainability risk) as we move into "very bad" times (between -4 and $3 \%$ ), that is, when economy is still well below capacity. The adjustment steps up even more during "bad times" (a gap is between -3 and -1.5\%), at the first sign of recovery (when actual growth exceeds potential growth). One implication of this complex rule is the presence of "steps" which have the unpleasant implication of requiring different fiscal efforts for countries in very similar cyclical conditions (just before/after the thresholds). More importantly, fiscal contractions are still required during bad times, so that the pro-cyclical bias is alive and kicking.

A final difficulty, is that the guidelines share the plethora of SGP indicators (structural unemployment rates, non-accelerating wage rates, potential output, output gaps, cyclically adjusted balances) that are subject to erratic revisions with far-reaching and possibly misleading implications for policy (see Tereanu, E, A Tuladhar, and A Simonem, 2014). As a case in point, Ireland in 2009 and 2011 saw a large flow of emigration to the UK as a result of the recession. Calculations of potential output showed a large decline, as a consequence of a lower labour force. As a result, the ratio of budget balance to potential output soared, indicating a large expansion, while the government was actually tightening fiscal policy. 


\section{CONCLUSIONS AND SOME PROPOSALS}

It is unlikely that the current fiscal framework will enable the Eurozone to improve the trade-off between debt sustainability and divergence of unemployment, investment and, possibly, growth . Real divergence could become a very serious threat to the existence of common currency and undermine its support. The question is how to get rid of the "water" of economic divergence without sacrifying the "baby" of fiscal sustainability. The problem of possibly persistent "asymmetric shocks" has to be confronted both ex-ante and ex-post.

Ex-post, a country's recession should not simply be entitled to a slower domestic fiscal adjustment: it should be dealt at the level of the Euro area by stronger Euro area fiscal capacity. A Euro-budget for counter-cyclical policies should be created. It could be funded by committing shares of members' tax bases, say V.A.T. It could take the form of a European Unemployment Insurance scheme, and pool actual unemployment insurance schemes and resources. Eligibility criteria should be harmonised across participant countries, so that the duration of subsidies, their conditionality, the fraction of the last wage and so on, should be the same in all participant countries. Each country should maintain a balanced position in the fund, over a given period, say five years, so as to avoid a permeant subsidization of unemployment in the South by Northern Europeans. Participation in the fund could be voluntary, but conditional on meeting a number of requirements in terms of labor market flexibility and decentralization of wage bargaining. Politically, this step could show to Europeans that Europe exists and helps.

Ex-ante, the actual SGP framework should be drastically simplified. It's "control and punish" bureaucratic logic should be abandoned and incentives should play a major role. The "preventive arm" should focus on the sustainability of domestic and external debt only: these are the best indicators of country vulnerability to solvency and liquidity crises, and these variables have the largest impact on other euro members. These are "final" targets. Each country should negotiate a reasonable medium term adjustment path for the debt, a reduction of $x \%$ in the debt/GDP ratio to be achieved in, say, four years. This target should take into account the cost of structural reforms.

Rather than setting complex rules based on non-transparent indicators for deciding the desired fiscal effort, the corrective arm should simply provide sanctions proportional to the deviation from the $\mathrm{x} \%$ debt target, at the end of the period. If the country has managed to reduce the debt ratio by more than agreed, the extra points could be credited to the country so as to enable it to pursue more expansionary policies in the following period (a "point system" similar to that for driving license, see Manasse, 2007). Note that this system would not need any complicated "correction" for the cycle: each country would decide how to allocate the required consolidation effort over the four years, presumably choosing lower adjustment in bad times, to be made up in good times.

Such an incentive system would clearly require an effective enforcement system. Once a European Stabilization Fund were in place, the system would require a clear no-bail out commitment for insolvent governments, and the European Stability Mechanism (ESM) should be gradually transformed into a sort of a European Sovereign Debt Restructuring Mechanism (see Krueger, 2002). 


\section{REFERENCES}

T. Aksoy, "Essays in the Economics of Structural Reforms", 2014 (mimeo) Ph D Dissertation, Bocconi University

O.Blanchard and D.Leigh, 2013, "Growth Forecast Errors and Fiscal Multipliers", IMF WP 13/1

Oya Celasun, Xavier Debrun, and Jonathan D. Ostry, 2006, "Primary Surplus Behavior and Risks to Fiscal Sustainability in Emerging Market Countries: A "Fan-Chart" Approach, December 2006 Volume 53, Number 3

Gavin, M and R Perotti (1997), "Fiscal Policy in Latin America", in B S Bernanke and J Rotemberg (eds.), NBER Macroeconomics Annual 1997, Volume 12, Cambridge, MA: MIT Press: 11-72.

D. F. Gray, R. C. Merton, and Z Bodie, 2007, "Contingent Claims Approach to Measuring and Managing sovereign credit risk", Journal of Investment Management, Vol. 5, No. 4, (2007), pp. 528

Hull, John and Alan White (2000), "Valuing Credit Default Swaps I: No Counterparty Default Risk", Journal of Derivatives, 8(1):29-40.

Anne O. Krueger, 2002, “A new Approach to Sovereign Debt Restructring”, Washingtin DC, IMF

P. Manasse, 2007, "Deficit Limits and Fiscal Rules for Dummies”, IMF Staff Papers, Vol 54 n.3.

P. Manasse and N. Roubini, 2006, "Rules of thumb for Sovereign Debt Crises", Journal of International Economics, Vol 78 n.2

P. Manasse, 2014, "Time to scrap the Stability and Growth Pact", voxeu.org, http://www.voxeu.org/article/time-scrap-stability-and-growth-pact

P. Manasse, 2015, " The EU new fiscal flexibility guidelines: An assessment”, voxeu.org http://www.voxeu.org/article/eu-new-fiscal-flexibility-guidelines-assessment

P Manasse, G. Trigilia, 2010, "Will the Irish crisis spread to Italy? "voxeu.org 26 November 2010

D. Romer, 2011, Macroeconomic theory, Mac Millan

R. Mundell, 1961," A Theory of Optimum Currency Areas", American Econornic Review, Sept., 657-665.

A.Stuart, K.Ord and S.Arnold, 1998, Kendall's Advanced Theory of Statistics, Arnold, vol 1, , p. 351

Tereanu, E, A Tuladhar, and A Simone (2014), "Structural Balance Targeting and Output Gap Uncertainty", $\quad$ IMF Working $\quad$ Paper $\quad 14 / 107, \quad$ June. 


\section{APPENDIX}

\section{An application of the No Ponzi Game solvency condition}

Table 1 below describes the average rate of growth of the debt ratio and the average cost of debt, net nominal growth, in the period from 2000-2012. Solvency requires that the debt ratio growth rate is below the interest rate differential. It turns out that only a few countries (in yellow), Belgium, Cyprus, Malta, and Italy, not prima-facie examples of fiscal discipline, satisfy the "no Ponzi scheme".

Table 1: Solvent Countries (yellow) according to "No Ponzi Scheme"condition Country Growth debt/GDP Int. rate- Nom.Growth

\begin{tabular}{|l|r|r|}
\hline Austria & $4.32 \%$ & $4.17 \%$ \\
\hline Belgium & $2.87 \%$ & $4.20 \%$ \\
\hline Cyprus & $8.60 \%$ & $9.15 \%$ \\
\hline Estonia & $16.72 \%$ & $1.77 \%$ \\
\hline Finland & $5.16 \%$ & $3.70 \%$ \\
\hline France & $6.80 \%$ & $3.58 \%$ \\
\hline Germany & $4.86 \%$ & $2.50 \%$ \\
\hline Greece & $6.87 \%$ & $4.57 \%$ \\
\hline Ireland & $15.70 \%$ & $3.67 \%$ \\
\hline Italy & $3.61 \%$ & $4.40 \%$ \\
\hline Latvia & $24.94 \%$ & $3.04 \%$ \\
\hline Luxembourg & $20.26 \%$ & $2.35 \%$ \\
\hline Malta & $6.74 \%$ & $8.46 \%$ \\
\hline Netherlands & $5.82 \%$ & $3.66 \%$ \\
\hline Portugal & $10.58 \%$ & $4.03 \%$ \\
\hline Slovak Republic & $9.54 \%$ & $4.33 \%$ \\
\hline Slovenia & $11.75 \%$ & $4.75 \%$ \\
\hline Spain & $7.86 \%$ & $3.38 \%$ \\
\hline
\end{tabular}

Source: Author's calculation on World Bank data-

A country is solvent if the growth rate of the debt/GDP ratio is less than the interest rate-nominal growth rate differential

\section{An example of the lack of robustness of DSA}

Consider the following example. DSA is often used in order to calculate the maximum sustainable "long run" level of a debt relative to GDP, $\bar{b}$. This denotes a level above which debt may explode, and is given by the formula

$\bar{b}=\frac{1+n}{r-n} a$

where $a$ denotes the ratio of the primary balance to GDP, $n$ is the rate of growth of GDP, $r$ is the average real interest rate on debt. Assume that the fiscal authority can maintain a primary surplus of $1.5 \%$ of GDP in the long run, and that the real rate of interest is $2.5 \%$. Then the calculation implies that a country can sustain a debt as high as three times of GDP, if the long-run growth is forecast at 2 percent per year; the same country could sustain a debt of only $75 \%$ of GDP if growth turns out to be $1 / 2$ percent per year. Are such forecast errors implausibly high? Unfortunately, they are not. Figure 9 below shows the average forecast errors (left scale), made by the IMF during the period 2011-2013, for advanced economies. Growth in "Stressed Euro area economies" (Portugal, Ireland, Greece, Spain) turned out to be almost one and a half points below the forecasts. 
Figure 9: growth forecast error by the IMF (source: WEO October 2014)

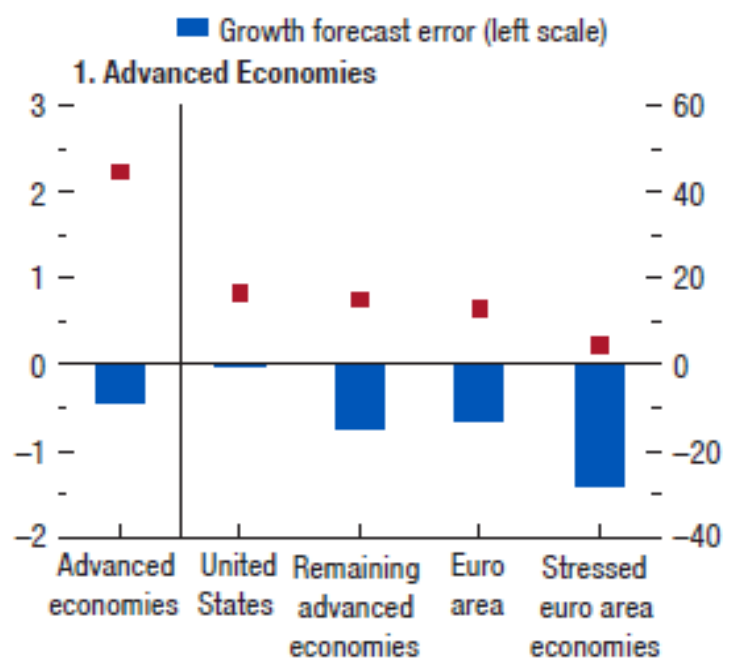

\section{Variance decomposition}

At a point in time, the cross country variance of this ratio, $\operatorname{Var}_{t}(B / Y)$ can be approximated by the sum of three terms in equation (1) (see Stuart and Ord, 1998). The first is the the cross-country dispersion of nominal debts, measured by the (squared) coefficient of variation at a point in time $\frac{\sigma_{\mathrm{B}}^{\mathrm{T}}}{\mu_{\frac{2}{2}}}$; the second is the cross-country dispersion of countries' nominal GDPs, measured againg by the squared coefficient of variation, $\frac{\sigma_{Y}^{\frac{\pi}{2}}}{\mu_{Y}^{2}}$; the third is the covariance between the countries' debts and outputs at a given time, $\operatorname{Cov}(B, Y)$

(1) $\operatorname{Var}\left(\frac{B_{i, t}}{Y_{i, t}}\right)=\frac{\mu_{B, t}^{2}}{\mu_{Y, t}^{2}}\left[\frac{\sigma_{B, t}^{2}}{\mu_{Y, t}^{2}}+\frac{\sigma_{Y, t}^{2}}{\mu_{Y, t}^{2}}-2 \frac{\operatorname{Cov}_{t}\left(B_{i, t}, Y_{i, t}\right)}{\mu_{B, t} \mu_{Y, t}}\right]$

\section{Fiscal reaction function}

The estimated equation is the following :

$$
\text { (2) } \triangle C A P B_{i t}=\alpha+\beta C A P B_{i t-1}+\gamma D E B T_{i t-1}+\delta G R O W T H_{i t-1}+\theta_{i}+\mu_{t}+\varepsilon_{i t}
$$

where $(\triangle) C A P B$ is the (change in) the cyclically adjusted primary balance expressed in terms of

potential output, DEBT represents the net general government debt as share of GDP, GROWTH is GDP rate of growth, $\theta_{i x} \mu_{t}$ and $\varepsilon_{i t}$ represent a fixed effect for country $i$, a set of time-dummies and

the error term, respectively. The coefficient of the lagged primary balance is expected to be negative, as a larger surplus this year should require a lower tightening next year to ensure debt stability. For the same reason, the coefficient of lagged net debt is expected to be positive - lower debt this year should reduce the required tightening next year. Finally, tax-smoothing/automatic stabilisers considerations would imply a positive coefficient on the GDP growth rate, as policy should tighten in good times and loosen in bad times. The estimation results are presented in Table 2 below. 
Table 2 . Regression results

\begin{tabular}{|l|r|r|r|r|r|r|}
\hline DCAPB & Coefficient & $\begin{array}{c}\text { Standard } \\
\text { error }\end{array}$ & \multicolumn{1}{c|}{$\mathrm{t}$} & $\mathrm{P}>|\mathrm{t}|$ & {$[95 \%$ confidence interval] } \\
\hline CAPB $_{-1}$ & -0.552 & 0.100 & -5.52 & 0.000 & -0.752 & -0.353 \\
\hline GROWTH $_{-1}$ & -0.229 & 0.089 & -2.59 & 0.012 & -0.406 & -0.053 \\
\hline DEBT $_{-1}$ & 0.011 & 0.010 & 1.18 & 0.242 & -0.008 & 0.0302 \\
\hline
\end{tabular}

The analysis considers the following EZ countries: Austria, Belgium, Estonia, Finland, France, Germany, Greece, Ireland, Italy, Luxembourg, the Netherlands, Portugal, Slovenia, Spain, Cyprus, Latvia, Malta, and the Slovak Republic, for the years 2008-2014. The data sources are the IMF and the OECD. 


\section{LIST OF ABBREVIATIONS}

$\mathrm{CV}$, Coefficient of Variation

DSA, Debt Sustainability Analysis

ESM; European Stability Mechanism

EU, European Union

EDP, Excessive Deficit Procedure

EIB, European Investment Banks

GDP, Gross Domestic Product

IMF, International Monetary Fund

MTO, Medium Term Objective

OECD, Organization for Economic Cooperation and Development

PPP, Private Public Partnership

SGP, Stability and Growth Pact

WEO, World Economic Outlook

\section{LIST OF TABLES}

Table 1: No Ponzi Game Solvency

Table 2: Regression Results

\section{LIST OF FIGURES}

Figure 1: Government Structural Balance Convergence

Figure 2a: Debt Convergence in the Euro Area

Figure 2b: Change in Debt Ratios

Figure 3: Unemployment Rate in the Euro Area

Figure 4: Investment in the Euro Area

Figure 5a: GDP Growth in the Euro Area

Figure 5b: Divergence in GDP

Figure 6: Unemployment vs Debt Dispersion

Figure 7: Decomposing the Debt/GDP Dispersion

Figure 8: The Cyclical conditions and fiscal adjustment

Figure 9: Growth forecast errors 


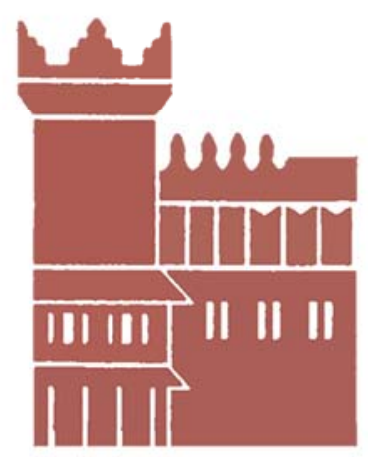

Alma Mater Studiorum - Università di Bologna DEPARTMENT OF ECONOMICS

Strada Maggiore 45

40125 Bologna - Italy

Tel. +39051 2092604

Fax +390512092664

http://www.dse.unibo.it 